\title{
Andrzej Walicki, Zarys myśli rosyjskiej od oświecenia do renesansu religijno-filozoficznego, Wyd. UJ, Kraków 2005, 862 strony.
}

Andrzej Walicki od lat prowadzi badania nad rosyjską myślą filozoficzną, społeczną, polityczną i religijną. Spod jego pióra wyszły traktujące o tej tematyce: Osobowość a historia. Studia z dziejów literatury i myśli rosyjskiej, Warszawa 1950; W kręgu konserwatywnej utopii. Struktura i przemiany rosyjskiego słowianofilstwa, Warszawa 1964; Rosyjska filozofia i myśl społeczna od Oświecenia do marksizmu, Warszawa 1973; Filozofia prawa rosyjskiego liberalizmu, Warszawa 1995; Marksizm i skok do Królestwa wolności. Dzieje komunistycznej utopii, Warszawa 1996; Idea wolności u myślicieli rosyjskich. Studia z lat 1955-1959, Kraków 2000.

Jedną z najnowszych jego prac jest bardzo obszerna monografia (862 strony ścisłego druku) Zarys myśli rosyjskiej od oświecenia do renesansu religijno-filozoficznego. Książka ta jest zmienioną i znacznie poszerzoną wersją opublikowanej w 1973 r. pracy Rosyjska filozofia i myśl społeczna od Oświecenia do marksizmu. Zasadnicza zmiana polega na rozszerzeniu ram czasowych omawianego zagadnienia do pierwszego dziesięciolecia XX wieku - tj. ukształtowania się tzw. Srebrnego Wieku kultury rosyjskiej.

Współcześnie prowadzone w Polsce badania nad myślą rosyjską koncentrują się na analizie poglądów wybranego myśliciela (prace M. Styczyńskiego, G. Przebindy, M. Bohuna, J. Dobiszewskiego, A. Kamińskiego, M. Kity), ewentualnie na analizie wybranego nurtu rosyjskiej filozofii, na przykład S. Mazurek.

Książka A. Walickiego wypełnia więc naukową lukę, prezentując czytelnikowi wszystkich ważnych myślicieli rosyjskich od drugiej połowy XVIII w. do początków XX wieku. Uwzględnienie w monografii problematyki filozofii i myśli społeczno-politycznej drugiej połowy XVIII w. autor tłumaczy jej ścisłym związkiem z problematyką dziewiętnastowieczną - okresem największego rozkwitu literatury rosyjskiej oraz tym, że za panowania Katarzyny II pojawiła się pogłębiona refleksja nad modelem monarchii i drogami rozwojowymi Rosji. Centralnym problemem myśli rosyjskiej XIX w. stała się sama Rosja i związane z tym pytania o to, kim są Rosjanie, skąd i dokąd zmierzają, jak mają postępować, by sprostać wyznaczonemu im zadaniu? A. Walicki zauważa, że szukając odpowiedzi na te pytania, Rosjanie „wykorzystywali swoisty «przywilej zacofania»: możliwość porównania własnego kraju z sytuacją krajów bardziej rozwiniętych oraz posługiwania się dorobkiem myśli zrodzonych w bardziej zaawansowanych na drodze postępu warunkach społecznych” (s. 18). Książkę zamykają rozdziały dotyczące myśli rosyjskiej pierwszego dziesięciolecia XX w. Wyznaczając taką cezurę czasową zamknięcia książki, autor wyszedł z założenia, że „rewolucja 1905 roku była naturalnym zakończeniem rosyjskiego wieku XIX. Autokracja rosyjska weszła w roku 1905 w fazę ostatecznego kryzysu; opozycja wobec niej przybrała zorganizowane formy polityczne, zdobyte swobody konstytucyjne umożliwiły jawność życia politycznego oraz szybki rozwój zinstytucjonalizowanych form społeczeństwa obywatelskiego - nie zahamowały jednak procesów rewolucyjnych. W ten sposób w dziejach monarchii rosyjskiej rozpoczął się rewolucyjny wiek XX" (s. 19). 
Książka podzielona jest na pięć części. Część pierwsza obejmuje okres najdłuższy, bo od panowania Katarzyny II, a ściśle od panowania Piotra I do wstąpienia na tron Mikołaja I; składa się z czterech rozdziałów, w których omówiona została myśl rosyjskiego oświecenia (rozdziały I i II), filozofia polityczna epoki Aleksandrowskiej (rozdział III) oraz prądy antyoświeceniowe XIX w. (rozdział IV). Część druga składa się z sześciu rozdziałów i obejmuje swoim zasięgiem epokę Mikołajowską. W rozdziałach tych omówione zostały poglądy Czaadajewa (rozdział V) oraz takie kierunki myśli rosyjskiej, jak okcydentalizm (rozdziały V i VIII), słowianofilstwo i antyokcydentalizm (rozdział VI). Omówione także zostały wpływy heglizmu na rosyjską myśl „lat czterdziestych” (rozdział VII), ideologia społeczno-polityczna oraz poglądy filozoficzne pietraszewców (rozdział IX), a także narodziny rosyjskiego socjalizmu (rozdział X). Złożona z sześciu rozdziałów część trzecia zawiera omówienie poglądów powstałych w czasach reform drugiej połowy XIX w., tj. „oświecicielstwa” lat sześćdziesiątych (rozdział XI), konserwatywnych ideologii powstałych po reformie uwłaszczeniowej (rozdział XII), ideologii narodnickich (rozdział XIII), anarchizmu (rozdział XIV), konserwatywnego liberalizmu Cziczerina (rozdział XV), a także pierwszej recepcji marksizmu w Rosji, jakiej dokonali narodnicy, formułując swoje poglądy w konfrontacji z marksizmem (rozdział XVI). Cześć czwarta obejmuje omówienie filozoficznych i religijnych poglądów okresu Rosji zreformowanej. Tworzą ją cztery rozdziały, w których omówione zostały poglądy Dostojewskiego i Tołstoja (rozdział XVII), poglądy wybitnego rosyjskiego filozofa Sołowjowa (rozdział XVIII), odmiany pozytywizmu i początki antypozytywistycznego przełomu (rozdział XIX) oraz metafizyczny idealizm (rozdział XX). Część piątą tworzą trzy rozdziały, w których omówione zostały trzy warianty marksizmu przełomu wieków (rozdział XXI), kryzys marksizmu (rozdział XXII) i renesans religijno-filozoficzny w pierwszych latach po rewolucji 1905 r. (rozdział XXIII).

Książka A. Walickiego jest kopalnią wiedzy o myśli rosyjskiej omawianego okresu. Czytelnik znajdzie w niej omówienie poglądów między innymi Aleksandra Hercena - „twórcy rosyjskiego socjalizmu” (s. 262), Borysa Cziczerina - „najwybitniejszego teoretyka dziewiętnastowiecznego liberalizmu w Rosji” (s. 433), prezentację filozofii Włodzimierza Sołowjowa - najwybitniejszego rosyjskiego filozofa XIX w., który - zdaniem autora - w pełni „zasługującego na włączenie w poczet klasyków filozofii współczesnej” (s. 564), a także poglądy Siemionna Desnickiego, „pierwszego rosyjskiego teoretyka prawa" (s. 48), Nikity Panina, którego Dyskurs o zaniku w Rosji wszelkiej formy rządów tudzież o wynikającym stąd chwiejnym położeniu zarówno cesarstwa, jak i monarchów jest ,jednym z celniejszych dzieł rosyjskiej myśli politycznej XVIII w.” (s. 67), Aleksandra Radziszczewa, myśliciela w pełni tego słowa oświeceniowego, którego Podróż z Petersburga do Moskwy ,jest jednym z najznakomitszych dzieł literatury oświeceniowej w skali europejskiej” (s. 74), czy Mikołaja Sperańskiego, „najciekawszego i najbardziej wpływowego myśliciela czasów Aleksandrowskich” (s. 99). Są to tylko przykładowe nazwiska z całej plejady omawianych przez autora myślicieli rosyjskich.

Warto dodać, że przy omawianiu dziejów rosyjskiej myśli A. Walicki uwzględnił poglądy Polaków: księcia Adama Czartoryskiego i Leona Petrażyckiego (s. 595-600). Leon Petrażycki do czasu odzyskania przez Polskę niepodległości żył i tworzył w kręgu kultury rosyjskiej. Uwzględnienie L. Petrażyckiego przy omawianiu dziejów myśli rosyjskiej jest dla Andrzeja Walickiego tak oczywiste, że nie próbuje nawet tłumaczyć swojej decyzji. Wyjaśnia natomiast umieszczenie w swojej pracy Adama Czartoryskiego: „zna- 
czenie Czartoryskiego w dziejach myśli rosyjskiej wynika z faktu, że to on właśnie, jako rosyjski mąż stanu, sformułował centralną ideę rosyjskiej polityki zagranicznej w pierwszym okresie rządów Aleksandra I: ideę prawa natury w stosunkach międzynarodowych jako środka do urzeczywistnienia trwałego pokoju. [Czartoryski - I.S.G.] podkreślał, że polityka powinna «łączyć się ze sprawiedliwością i moralnością», wyrażając "zasady powszechnego dobra narodów». Specyficznie polskim aspektem tego programu było skupienie uwagi na uetycznieniu stosunków, nie tylko między państwami, lecz również między narodami, wyraźnie od państw odróżnionymi” (s. 93). Na marginesie można dodać, że w pracy A. Walickiego występują również inne polskie akcenty, między innymi uwaga, że „hymn «Boże coś Polskę», kojarzony dziś ze sprzeciwem wobec obcej władzy napisany był przez Alojzego Felińskiego dla uczczenia pierwszej rocznicy utworzenia Królestwa, a jego refren brzmiał: «Naszego króla zachowaj nam Panie»" (s. 91). Chodziło oczywiście o cara Aleksandra I.

Poza walorami naukowymi niezwykłym atutem książki A. Walickiego jest klarowność tekstu i lekkość stylu. Poszczególne rozdziały poprzedzone są wprowadzeniem szkicującym tło epoki oraz wyjaśniającym stosowaną przez autora terminologię. Przy omawianiu stanowisk poszczególnych myślicieli Andrzej Walicki wskazuje czytelnikowi źródła poglądów danego myśliciela, a także wyjaśnia przyczyny ewolucji poglądów, czy wręcz diametralnej zmiany wcześniej zajmowanego stanowiska. Jest to niezwykle istotne, gdyż ułatwia czytelnikowi zrozumienie stanowiska, z którym jest zaznajamiany. Przykładem może być opisana przez A. Walickiego przemiana poglądów Michała Katkowa - głównego ideologa rosyjskiego nacjonalizmu. Początkowo Katkow był polonofilem. Królestwo Kongresowe łączyło w jego oczach wolnościową tradycję dawnej Rzeczypospolitej z nowoczesną kulturą prawną, zawartą w obowiązującym na jego terytorium Kodeksie Napoleona. Według Katkowa mogło ono być czynnikiem przyspieszającym zbliżenie Rosji do Zachodu. Andrzej Walicki wyjaśnia, że wybuch powstania listopadowego, a zwłaszcza zamach na wielkiego księcia Konstantego wpływają na zmianę stosunku Katkowa do Polaków; ewolucję tę pogłębia jeszcze wybuch powstania styczniowego. Ostatecznie Katkow dochodzi do przekonania, że na słowiańskim wschodzie Europy nie ma miejsca na dwa silne „narody historyczne”, dlatego „Polacy i Rosjanie nie są jedynie rywalami, ale »wrogami do końca", niemogącymi istnieć obok siebie” (s. 327).

Chociaż książka A. Walickiego dotyczy dziejów myśli rosyjskiej, to w rozdziale pierwszym, traktującym o kierunkach i prądach myśli oświeceniowej, czytelnik znajdzie interesujące informacje dotyczące reform Piotra I. Z pracy tej można się między innymi dowiedzieć, że Piotr I nosił się z zamiarem uczynienia języka holenderskiego językiem rosyjskiej elity (s. 36). Interesująca jest zaproponowana przez autora interpretacja motywów wprowadzenia przez Piotra I dekretu o następstwie tronu, zgodnie z którym monarcha miał prawo wyznaczyć swojego następcę spośród członków rodziny panującej według własnej woli. Dekret ten zrywał z dziedziczeniem tronu na zasadzie primogenitury, „zastępował ją wyborem odpowiedniego kandydata (spośród osób spokrewnionych lub spowinowaconych z Romanowami) na zasadzie jego «zdatności» do kontynuowania reform" (s. 31). Wypada się zgodzić z autorem, że w dekrecie tym dynastyczne uzasadnienie sprawowania władzy ustąpiło miejsca uzasadnieniu teleologicznemu.

$\mathrm{Z}$ kolei na stronie 30. czytelnik znajdzie informację, że rezultatem przeprowadzonych reform było „zastąpienie patrymonialnego pojęcia państwa (jako własności monarchy), pojęciem państwa jako dobra publicznego (bien public), ogólnonarodowego, 
a więc czegoś wyższego i odrębnego niż monarcha” (s. 30). Autor pisze dalej, że Piotr I „był pierwszym rosyjskim carem, który traktował samego siebie jako sługę państwa; za cel swych działań uznał »dobro ogółu«, powoływał się na ten cel w swych dekretach, wprowadził nawet zwyczaj publicznego wyjaśniania swych działań na łamach rządowej gazety" (s. 30). Uzasadniając swoją tezę, Andrzej Walicki przywołuje stanowisko najbliższego współpracownika cara, Teofana Prokopowicza, który w 1721 r. stanął na czele Najświętszego Synodu. Prokopowicz uzasadniał w swych pracach koncepcję monokracji, rządów sprawowanych dla dobra ogółu, władzy przeciwstawiającej się wszelkim partykularyzmom w imię ogólnopaństwowego interesu, utożsamianego z dobrem całej ludności. Analogiczną koncepcję Andrzej Walicki odnajduje u Wasilija Tatiszczewa, autora pisanej w latach 1727-1739 pięciotomowej historii Rosji, który dowodził w swym dziele, że w państwie o tak wielkim obszarze i otwartych granicach jak Rosja efektywną obronę dobra ogółu może zapewnić tylko monarchia.

Ciekawe jest również omówienie - jak to autor nazwał - eksperymentu z powołaną w 1767 r. Komisją Legislacyjną oraz skierowanej do tej Komisji Instrukcji. Jak wiadomo, Instrukcję napisała Katarzyna II, obiecywała w niej stosować się do zasad prawa natury i uczynić z Rosji kraj praworządny, szanujący przyrodzone prawa wszystkich ludzi. Oceniając Instrukcję, autor podkreśla, „paradoksalny nieco fakt [...] że właśnie cesarzowa Rosji, czyli władczyni najbardziej autokratycznego państwa szeroko pojętej Europy, okazała się monarchinią najdalej idącą w deklarowaniu solidarności z zasadami oświeceniowej filozofii prawno-politycznej [...] [oraz że - I.S.G.] Instrukcja Katarzyny była pierwszą oficjalną, dokonaną z wyżyn tronu, proklamacją praw człowieka - nie tylko w Rosji, lecz w całej Europie" (s. 39).

Z kolei odnosząc się do Komisji Legislacyjnej, A. Walicki przez wykrzyknik podkreśla demokratyczny, jak na tamte czasy, sposób jej powołania. Komisja Legislacyjna składała się bowiem z 564, powołanych w drodze wyborów, przedstawicieli stanów, w tym z ponad 100 przedstawicieli, tzw. chłopów skarbowych. Jednocześnie autor zwraca uwagę, że obrady Komisji wykazały obłudę carycy; z chwilą, gdy pojawiły się projekty idące dalej niż Instrukcja cesarzowej, odroczyła obrady, by ich już nie wznowić. W swoich rozważaniach A. Walicki konkluduje: „niepowodzenie eksperymentu z Komisją było nie tylko zdemaskowaniem autokratycznej obłudy, lecz również klęską optymistycznych złudzeń »filozofa na tronie«. Niewesołe refleksje nasuwał już stosunek do wyborów: większość wyborców traktowała funkcje przedstawicielskie jako ciężar, od którego każdy pragnął się uchylić, zdarzało się, że wybierano ludzi najbardziej nielubianych - delegaci tacy komicznie uskarżali się, że wybrano ich, aby im »zrobić na złość«” (s. 40).

Cała książka Andrzeja Walickiego jest niezwykle wartościowa. Jednakże na szczególną uwagę zasługuje rozdział XXI, w którym autor omówił marksizm integralny Jerzego Plechanowa, wspierany przez ministra Wittego marksizm legalny oraz rewolucyjny marksizm Lenina. Ze zrozumiałych względów szczególne znaczenie należy przypisać teorii Lenina. Omawiając stanowisko wodza rewolucji, autor skoncentrował się na teorii partii-awangardy klasy robotniczej, zawartej przez wodza rewolucji w Co robić?, gdyż szczegółowe omówienie poglądów Lenina wykraczałoby poza chronologiczne ramy książki wyznaczone rewolucją 1905 r. Charakteryzując leninowskie pojmowanie bolszewizmu, musiał jednak, tam gdzie to konieczne, uwzględnić „te jego aspekty, które rozwinęły się, lub po prostu, odsłoniły w okresie późniejszym - zapoczątkowanym przez kryzys rewolucyjny, powstanie partii politycznych oraz ich udział we władzy" (s. 673). 
Autor słusznie zauważa, że nowością na gruncie marksizmu była głoszona przez Lenina teza, że władza proletariatu musi być dyktatorska, tzn. opierająca się bezpośrednio na przemocy oraz nieograniczona przez żadne prawa. Gdy tymczasem klasyczny marksizm „pojmował dyktaturę proletariatu nie jako system dyktatorskiej władzy, lecz jako hegemonie klasy robotniczej, taka jaka urzeczywistniła się w Komunie Paryskiej” (s. 673).

Książka Andrzeja Walickiego jest dziełem opartym na rzetelnych badaniach, uwzględniającym niezwykle bogatą literaturę źródłową i opracowania. Monografia ta jest dziełem kompletnym, w sposób niezwykle lekki dokonującym szczegółowej syntezy rosyjskiej myśli od Oświecenia do pierwszego dziesięciolecia XX w., wypełniającym w tym zakresie lukę naukową.

Ireneusz S. Grat 